„Bohemistyka” 2021, nr 3, ISSN 1642-9893

Grażyna BALOWSKA

DOI: $10.14746 /$ bo.2021.3.9

Uniwersytet Opolski

\section{Kobieta w czeskich dowcipach}

Keywords: Czech joke, humor, positive and negative stereotype, stereotype of woman Słowa kluczowe: czeski dowcip, humor, stereotyp pozytywny i negatywny, stereotyp kobiety

\section{Abstract}

Authoress, in her article, presents question of woman's stereotype in the background of issue referring to a view of the world, which is an ordinary knowledge of language's user concerning surrounding reality, and a picture of a woman is its fragment. She notices that stereotype can be positive or negative, or it can connect both elements. Jokes analyzed in article present a woman in a negative way. Anti-model is formed opposite to standard set of characteristics, which, according to common social opinion, a woman should has. Described picture depends on a convention of type, to which joke belongs, because it allows to look at negative feminine characteristics with humor. Authoress emphasizes that picture of a woman in Czech jokes has universal character, international.

W swoim artykule autorka zwraca uwagę na problematykę stereotypu kobiety, który reprezentuje potoczną wiedzę użytkownika języka na temat wskazanego wycinka otaczającej go rzeczywistości. Wpisuje się zatem w szerszy obraz świata utrwalony w języku czeskim w postaci dowcipów. Autorka zwraca uwagę, że stereotyp może być pozytywny bądź negatywny lub może łączyć oba aspekty. W dowcipach analizowanych w artykule kobieta przedstawiona jest w sposób negatywny. Powstaje więc antymodel, który jest przeciwieństwem wzorcowego zestawu cech, jakimi, zgodnie z powszechną opinią społeczną, powinna charakteryzować się kobieta. Obraz ten jest jednak zależny od konwencji gatunku, jakim jest dowcip językowy, który pozwala patrzeć na negatywne kobiece cechy $\mathrm{z}$ humorem i wyrozumiałością. Autorka podkreśla, że wizerunek kobiety w czeskich dowcipach ma charakter uniwersalny, międzynarodowy.

Dowcip jako tekst stanowi wypadkową fenomenu śmiechu jako specyficznie ludzkiej zdolności, o niezwykłości której Henri Bergson twierdzi, iż wynika ona $\mathrm{z}$ faktu, że człowiek jako jedyna istota wśród zwierząt potrafi się śmiać i wzbudzać śmiech także u innych (Bergson 2000, s. 9). Specyfikę owego fenomenu podkreśla także Sylvie Richterová, twierdząc, że „Smích je snad nejpodivuhodnější projev lidského bytí. Můžeme se smát nejrůznějšími způsoby nejrůznějším věcem, můžeme smích vyvolávat záměrně i nechtěně, nemůžeme ho však dostatečně definovat ani žádným vyčerpávajícím způsobem popsat, klasifikovat, analyzovat" (Richterová 1997, s. 9).

Należy zatem stwierdzić, że dowcip stanowi swoisty gatunek mowy o podstawowej, określonej niejako z założenia funkcji ludycznej. Jest to zatem krótki utwór, prymarnie oralny, posiadający anonimowy charakter i służący rozśmieszeniu odbiorcy (por. np. Borecký 2000, Brzozowska 2008, Buttler 2001, Kadłubiec 1995, Krzyżanowski 1977, Simonides 1984, Skudrzykowa 2000) ${ }^{1}$. Efekt komiczny osiagany jest bądź za pomocą środków językowych, np. gry słów - mamy wówczas do czynienia z dowcipem językowym, którego śmieszność wynika z określonej struktury powierzchniowej tekstu, bądź za pomocą opisu określonej śmiesznej sytuacji, mówimy wówczas o dowcipie sytuacyjnym $^{2}$. W naszym artykule przedmiotem analizy będą oba typy dowcipu.

Danuta Buttler, autorka teorii polskiego dowcipu językowego, podkreśla także istotny wyznacznik tego typu tekstów, jakim jest występowanie zaskakującej puenty. Badaczka zauważa:

${ }^{1}$ Badania dowcipów językowych przebiegają obecnie w ramach szeroko pojęte humorologii jako interdyscyplinarnej dziedziny naukowej rozpatrującej różnorodne aspekty humoru, np.: lingwistyczne, literaturoznawcze, kulturoznawcze, antropologiczne, psychologiczne, socjologiczne. Por niezwykle obszerna literature przedmiotu, chociażby np. serię wydawniczą Humour and Culture, czasopisma, np. „International Journal of Humor Research”, „The European Journal of Humour Research", czy prace zbiorowe rozpatrujace humor w ujeciu lingwistyczno-kulturowym, np. Humor i karnawalizacja we współczesnej komunikacji językowej (Lublin 2007), Humor w perspektywie kulturowo-językowej (Lublin 2013), Świat humoru (Opole 2000) itd

${ }^{2}$ Szerzej na temat podziału dowcipów na językowe i sytuacyjne (referencyjne) por. Brzozowska 2008, s. 53n. Autorka wychodzi od przywołania testu empirycznego Cycerona, a następnie szczegółowo omawia analizę amerykańskich dowcipów przeprowadzona przez zespół badaczy pod kierownictwem Salvatore Attarda w ramach współczesnych badań humorologicznych. 
Można bowiem słowo d ow c i p rozumieć [...] szczegółowiej - jako nazwę ściśle określonej struktury o stałej kompozycji, charakteryzującej się krótkością i zaskakującą pointą, a więc nazwę pewnego gatunku literackiego o charakterze komicznym (Buttler 2001, s. 31).

Dowcip, rozumiany jako gatunek tekstu, jest nośnikiem określonych treści kulturowych i stanowi utrwalony w języku obraz pewnego wycinka rzeczywistości, obraz ukształtowany w oparciu o wiedzę potoczna przeciętnego użytkownika danego języka i wchodzący w skład szeroko pojmowanego językowo-kulturowego obrazu świata. Według Jerzego Bartmińskiego językowy obraz świata to potoczna, tzw. naiwna interpretacja rzeczywistości, oddająca mentalność użytkownika języka i odpowiadająca zarówno jego punktowi widzenia, jak i jego potrzebom (Bartmiński 2006, s. 14). Jest ona antropocentryczna i etnocentryczna i jako taka prezentuje aksjologiczny ogląd rzeczywistości, który stanowi nieodłączny element przednaukowego, potocznego postrzegania świata. Składają się na nią stereotypy rozumiane jako sądy wartościujące, obejmujące $\mathrm{z}$ jednej strony sądy pozytywne, z drugiej zaś negatywne (Bartmiński 2007, s. 59n.).

W przypadku interesujących nas tu dowcipów mamy do czynienia z sądami wartościującymi dotyczącymi głównie cech i działań człowieka, a obraz w nich przedstawiany jest z założenia przejaskrawiony, wyolbrzymiony, utrwalający stereotypy negatywne, będące w opozycji do funkcjonujących w społeczeństwie stereotypów pozytywnych - wzorców pożądanych i wskazywanych do naśladowania, obejmujących dodatnio wartościowane cechy, postawy czy zachowania.

Poniżej przedstawimy obraz kobiety utrwalony w czeskich dowcipach, które zostały wyekscerpowane głównie z dwu zbiorów Špalíček dobrých českých vtipů (I 2005, II 2006) oraz z Internetu. Prezentacji materiału językowego dokonamy w oparciu o wskazane przez Eugenię Mandal cztery główne komponenty stereotypu kobiecego, wyło-

${ }^{3}$ E. Mandal przytacza następującą definicję stereotypów związanych z płcią: „Uproszczone sądy i koncepcje zachowania osobników żeńskich lub męskich, podzielane przez ogół danego społeczeństwa i uczone w procesie wzrastania i socjalizacji w tym społeczeństwie" (Mandal 2003, s. 38). nione w badaniach psychologicznych prowadzonych nad stereotypami płciowymi, reprezentujące oczekiwania społeczne wobec kobiety: osobowość, role społeczne, wygląd zewnętrzny i zawód ${ }^{4}$.

W tej perspektywie zatem najistotniejsze w kształtowaniu stereotypu kulturowego płci są postawy moralne i społeczne, które są poddawane silnej ewaluacji przez członków danego społeczeństwa. Jak twierdzi Józef Kąś:

Należy przy tym wyraźnie podkreślić, że pierwszoplanowe jest tu wartościowanie społeczne z punktu widzenia znaczenia danej postawy w życiu społecznym; marginalne znaczenie ma natomiast tworzenie stereotypowego wizerunku uwzględniającego cechy zewnętrzne (Kąś 1994, s. 120).

Badany przez nas materiał potwierdza powyższy sąd badacza, znaleźliśmy bowiem najwięcej przykładów odwołujących się do cech wewnętrznych kobiety, jej osobowości i pełnionych przez nią ról społecznych, mniej natomiast do cech zewnętrznych i wykonywanego zawodu. Na podstawie wybranych dowcipów przyjrzymy się poniżej temu, co stanowi źródło śmieszności w wizerunku kobiecym, na który składają się cztery kategorie: cechy charakteru i osobowości, role społeczne i postawy, wygląd zewnętrzny oraz zawód.

${ }^{4}$ Autorka przedstawia model kobiecości obejmujący nastepujący zestaw cech oczekiwanych od kobiety: 1. Osobowość: emocjonalność, zdolność do poświęceń, delikatność, czułość, troska o uczucia innych, umiejętność rozumienia innych, ciepło w relacjach z innymi, pomaganie. 2. Role społeczne: jest źródłem wsparcia emocjonalnego dla innych, zarządza domem, opiekuje się dziećmi, odpowiada za urządzenie domu. 3. Wygląd zewnętrzny: delikatny głos, schludność, wdzięk, miękkość ruchów. 4. Zawód: terapeutka, telefonistka, logopeda, nauczycielka w szkole podstawowej, pielęgniarka (Mandal 2003, s. 39).

Należy dodać, że autorka zwraca także uwagę na badania K. Deaux i L. Lewis (1984), którzy doszli do wniosku, że cechy żeńskie należy rozpatrywać w opozycji do cech męskich zgodnie z wyraźnym postrzeganiem przez jednostkę dychotomii męskość-kobiecość. Dychotomia ta jest odzwierciedleniem procesów socjalizacji jednostki. Problematykę stereotypu męskiego utrwalonego w czeskich dowcipach zaprezentowaliśmy w publikacji Wizerunek mężczyzny w czeskich dowcipach (Balowska 2014). 


\section{Cechy charakteru i osobowości}

W analizowanych dowcipach poświadczone zostały następujące cechy charakteru i osobowości kobiety:

- g a d a t 1 i w o ś ć: Povídá otec dceři, která právě položila sluchátko:

„Co se stalo, že jsi mluvila jenom čtvrt hodiny?”

„Byl to omyl."

- p l o t k a r s t w o: Povídají si dvě přítelkyně:

„Víš, o Martině nemůžu říct nic špatného,” ř́ká jedna.

Ta druhá na to: „No, tak tedy budeme mluvit o někom jiném.”

- g ł u p o t a: Žena myslí bud' na nic nebo na něco podobného.

- z a c h ł a n n o ś ć: Co mají společného ženy a hurikány?

Když přijdou, jsou vlhké a horké, když odcházejí, berou si auta a domy.

- z a w i ś ć: „Podle mě je žena nejšt’astnější, když se vdá za muže, kterého chtěla.” „Ne, podle mě je nejšt’astnější, když si vezme muže, kterého chtěla jiná.”

- z m i e n n o ś ć: Žena je zvláštní tvor. Ve společnosti chce, aby si muži všimli, že má nové šaty, doma žádá, aby si muž všiml, že nemá nové šaty.

- n i e sło w n o ś ć: „Ř́íkala jsem, že tam za pět minut budu! Nechápu, proč mi co pưlhodiny voláś!"

- r o Z w i ą zło ś ć s e k s u a $1 \mathrm{n}$ a: Na policii přiběhne žena a rozrušeně ř́íá: „Před chvilkou mě tamhle v parku znásilnilo deset chlapů."

„Nebojte se,” přeruší ji policista, „my je všechny dostaneme.”

„Ale já nechci všechny,” odpoví žena, ,potřebuji jen, abyste mi našli ty, kteří byli v pořadí třetí, čtvrtý a sedmý."

- nie nawiazuje prawdziwej przyjaźni z kobietami: Ženské přátelství:

Manželka nepřijde večer domů a ráno říká, že nocovala u kamarádky. Manžel obtelefonoval jejích 10 nejlepších kamarádek a všechny řekly že ona u nich nenocovala

Mužské přátelství:

Manžel nepřijde večer domů a ráno říká, že nocoval u nejlepšího kamaráda. Manželka obtelefonovala jeho 10 nejlepších kamarádů a $5 \mathrm{z}$ nich řeklo, že on u nich nocoval, dalších pět jí sdělilo, že on u nich doposud je.

- je s t zły m k i e r o w c ą: Žena za volantem je jako hvězda na nebi. Ty jí vidíš, ale ona tebe ne.
- i ry tu j e m ęż c zy zn ę: Život ženy se dělí na tři období:

1. Jde na nervy svému otci.

2. Jde na nervy svému muži.

3. Jde na nervy svému zeti.

Wśród cech przynależnych do tej kategorii wyróżniamy takie przywary, które charakteryzują kobiete w każdym wieku i sa niezależne od pełnionej przez nią roli i zajmowanej pozycji społecznej. Wyraźnie uwypukla się tu skłonność od zbytniego mówienia, rozwodzenia się nad czymś, czyli g a d a t 1 i w o ść. Cechę tę Katerina Kedron uznaje za jedna $\mathrm{z}$ najbardziej typowych negatywnych charakterystyk kobiety, jakie zostały utrwalone w czeskiej frazeologii, choć nie wyklucza to faktu, że także mężczyzna może się cechować gadatliwością (Kedron 2014, s. 80).

W naszym materiale pojawił się także dowcip, który prezentuje humorystyczne wyjaśnienie z perspektywy kobiety tego, że mówią one więcej niż mężczyźni. Warto go tu przytoczyć:

Manžel čte manželce článek o tom, kolik slov muži a ženy používají denně - 30000 ženy a 15000 muži.

Žena odpoví: „To proto, že my ženy vám mužům musíme všechno opakovat.”

Muž se na to otočí k ženě a ptá se: „Co?”

Inaczej rzecz ma się w przypadku kolejnej typowej przywary, jaka jest p lotka rstwo, ponieważ szerzenie niesprawdzonych, często kłamliwych wiadomości szkodzących czyjejś opinii to cecha, którą przypisuje się tylko kobiecie. Według K. Kedron stanowi ona jedną z tzw. uniwersalnych cech kobiecych w zachodnim kręgu kulturowym (Kedron 2014, s. 77).

Obraz kobiety utrwalony w badanych dowcipach obejmuje także krytykę stanu jej aktywności myślowej. W androcentrycznym postrzeganiu, jakie jest typowe dla potocznego wartościowania kobiety w ujęciu społeczno-kulturowym, jest bowiem ona traktowana jako ograniczona intelektualnie. Stereotypowym przykładem g ł u p o ty kobiety w dowcipach jest blondynka. Porównajmy poniższy przykład: 
Blondýnka letí do Londýna. Jak ji připravíte o místo u okna?

Řeknete jí, že sedadla do Londýna jsou v prostřední řadě.

Należy tu dodać, że owo stereotypowe wyobrażenie stoi w sprzeczności z badaniami empirycznymi, jakie w latach osiemdziesiątych XX w. zostały przeprowadzone przez Center for Human Resource Research (CHRR) na Ohio State University ${ }^{5}$. Zgodnie z wynikami eksploracji naukowych amerykańskich badaczy naturalne blondynki miały wynik IQ przeciętnie o 3 punkty wyższy niż brunetki, kobiety rudowłose i szatynki.

Stereotypowość myślenia przeciętnego użytkownika języka na temat kobiecych zdolności umysłowych przejawia się także w podejściu do kobiet urodziwych i dbających o wygląd zewnętrzny. W jego oczach każda piękna kobieta jest głupia, co poświadcza poniższy dowcip:

Nikdy nevěřte jasu v očích krásné ženy. Je to jen slunko, které prosvítá skrz její dutou hlavu.

Inna kobieca wada ujawniajaca się w analizowanych tekstach jest z a c hła nn o ść, która dotyczy kwestii materialnych. Kobieta postrzegana jest jako ta, która nieustannie chce posiadać coraz więcej dóbr materialnych, zwłaszcza pieniędzy. Ową chciwość ujmuje także dalszy przykład:

Co je patnáct centimetrů dlouhé, pět široké a ženské po tom hrozně šilí? Peníze.

Z kobiecą zachłannością i chciwością powiązana jest następna przywara, czyli zaw iść. W badanym materiale jest zatem negatywnie wartościowany taki sposób zachowania kobiety, w którym kieruje się ona zawiścią w dążeniu do celu - posiadania czegoś, co ma już inna osoba, szczególnie zaś takie postępowanie, kiedy mamy do czynienia $\mathrm{z}$ najwyższym stopniem zawiści prowadzacym do przedmiotowego traktowania człowieka, tu: mężczyzny.

${ }^{5}$ Por. informację o powyższych badaniach https://naukawpolsce.pap.pl/aktual nosci/news\%2C408939\%2Cnie-takie-glupie-blondynki.html [dostęp 20.05.2021].
Zgodnie z powszechnym mniemaniem, zapisanym już przez Wergiliusza, dla kobiety jest charakterystyczna $\mathrm{z} m$ i e $\mathrm{n} n$ o ść ć. Także $i$ ta jej wada została zarejestrowana w naszym materiale. Nie idzie tu jedynie o to, że jest niestała w uczuciach, ale głównie o fakt, że jej zachowanie trudno przewidzieć. Odzwierciedleniem tej cechy jest także przekonanie, że kobieta nie mówi tego, co myśli. Przywołajmy tu dodatkowo dowcip, obrazujący to wyobrażenie:

Víš, kdy je možné, že žena řekne to, co si myslí?

Jen když žena nemyslí na to, co ř́ká, je možné, že řekne to, na co myslí.

Kolejnym elementem stereotypowego postrzegania kobiety utrwalonego w analizowanych tekstach jest jej n i e sło w n ó ć. Negatywnie więc jest wartościowane niedotrzymywanie słowa, terminów czy obietnic.

Ważną kwestią w relacji płci jest sfera seksualności. W związku $\mathrm{z}$ tym $\mathrm{w}$ dowcipach ujemnie ewaluowana jest kobieca rozw i a zł o ś ć, jej rozpustne życie pozbawione zasad moralnych, które budzi powszechne zgorszenie.

Negatywny stereotyp kobiety przedstawiony w naszym materiale obejmuje także cechę, której brakuje jej we wzajemnych relacjach z przedstawicielkami swojej płci, mianowicie nie potrafi nawiązać prawdziwej przyjaźni z kobietami. Nie umie ona wytworzyć z innymi kobietami silnej przyjacielskiej więzi i stosunków opierających się na zaufaniu i wzajemnej pomocy.

Meska perspektywa postrzegania kobiety uwzględnia także ocenę tego, jak „,radzi sobie za kierownicą”. W dowcipach zostało utrwalone potoczne przekonanie, że kobieta ze swej natury nie jest predestynowana do prowadzenia samochodu i dlatego nie może być dobrym kierowca, co utrwala negatywny społeczno-kulturowy stereotyp kobiety złe g o ki erow cy.

Generalizując, można powiedzieć, że wszystkie powyższe cechy kobiety stanowią przyczynę, dla której bez względu na swój wiek,

\footnotetext{
${ }^{6}$ Por. Niestała i zmienna jest zawsze kobieta (Varium et mutabile semper femina, Wergiliusz, Eneida 4, 569).
} 
rolę i pozycję społeczną i rytuje mężczyznę, podudza go do złości, wprowadza w stan rozdrażnienia. Sąd ten wpisuje się w powszechnie panujące przekonanie o nieustannej walce płci i różnicach niejednokrotnie niemożliwych do zniwelowania.

\section{Role spoleczne i postawy}

Powyższa kategoria obejmuje role, jakie zostały przypisane kobiecie w kulturze w odniesieniu do jej wieku (etapu życia) i zajmowanej pozycji w społeczeństwie. $\mathrm{W}$ analizowanym materiale zarejestrowane zostały cztery typy ról społecznych: młoda kobieta, żona, teściowa i stara panna. Poniżej prezentujemy, jak w dowcipach postrzegana jest kobieta w zależności od pełnionej przez nią roli społecznej, jakie cechy zostały jej przypisane zgodnie $\mathrm{z}$ wyobrażeniami i przekonaniami utrwalonymi społecznie. Kobieta w dowcipach pełni następujęce role:

1. Młodej k obiety, odznaczajcej się cechami:

-n a i w n o ś ć: Starostlivý otec se ptá své dcery, jestli si je jistá, že to s ní její př́tel myslí vážně. Dcera odpovídá:

"Myslím, že jo, tati. Zrovna včera se ptal, kolik vyděláváš, jaká jídla maminka vaři a jestli se s vámi dá vydržet."

- n a s t o l e t n i a m a tk a: Baví se dvě šestnáctileté: „Máš už kulka?”

„Ne, zatím jen holčičku.”

2. Ż o n y, odznaczajcej się cechami:

- je st kłót li iw a: Novomanžel povídá:

„Drahoušku máme teprve několik týdnů po svatbě a ty už se chceš hádat?' „No a co, vždyt' jsem na to taky tři roky čekala."

- z d r a d z a m ę ż a: Můj ex mě chtěl ztrapnit před svými kamarády... Řekl, že jsem špatná v posteli... No, měli jste vidět ten výraz, kdyžs s ním ani jeden nesouhlasil.

- jest rozrzutna: Průměrná rychlost pohybu manželky v obchodě $=$ 2000,- Kč/hod.

- ni e potrafi dobrze g ot ow a ć: „Proč se na Vás manžel tak rozzlobil?" ptá se vyšetřovatel.

„Zcela bezdůvodně mě napadl, že neumím vařit,” sděluje žena.
„A čím Vám rozbil tu hlavu?"

„Čerstvým knedlíkem.”

- dominuje w małżeń stwi e: „Včera jsme se s manželkou strašně pohádali, ale nakonec přilezla po kolenou.” „A co řikala?” „Vylez zpod toho gauče, ty srabe!!!”

- j e s t w r og a i n i e b e z p i e c z n a: Volá ženská své známé:

„Představ si, že jsme se s Fandou po patnácti letech manželství poprvé, ale skutečně poprvé pořádně pohádali."

„No, to se normálně stává v rodinách i před svatbou, to si tak neber, to se vždycky časem srovná."

„No jo, ale co mám dělat s tou mrtvolou?"

- je s t m ś c i w a: Můj bývalý mě nechal, odešel za podstatně mladší. Já si nabrnkla jejího tatíka a budu mu dělat tchýni, hajzlovi.

- m a n i p u l u j e: Ona: Udělala jsem ti palačinky jako omluvu za to nabouraný auto. On: Cože si udělala? Ona: Palačinky, seš snad hluchej?

- przynosi nieszczęści e mężczyźn i e: Jakej je rozdíl mezi ženskou a kominíkem??

Velkej. Už si někdy viděl nějakou ženskou, která by někomu přinesla štěstí?

3. T e ś c i o w e j, odznaczajcej się cechami:

-je s t zło śl i w a: „Slyšel jsem, že tvoje tchýně dostala otravu krve. Co se jí stalo?"

„Kousla se do jazyku!”

- jest męcząca i dokuczliwa: Jaký je rozdíl mezi mouchou a tchýní?

Moucha otravuje jen v létě.

- w s z y s t k o wi e: Inzerát:

Prodám všeobecnou encyklopedii, 45 dílů. Již ji nepotřebuji, před dvěma měsíci jsem se oženil a moje tchyně ví naprosto všechno!

- b u d z i p o s tra c h: „Proč si myslíte, že byl váš soused opilý?” ptají se u soudu.

„Protože vykřikoval, že se nebojí ani ženy, ani tchýně.”

-je s t ob i e k te m a ta ków zi ę cia: „Včera mě tak nasrala tchýně, že jsem se neovládl."

"A co jsi ji udělal?"

„Schoval jsem jí zuby.” 
4. Starej panny, która ma negatywny stosunek do se k s u a ln o ś c i: Dvě staré panny sledují jak kohout honí slepici. Slepice utíká utíká až vběhne na silnici, kde ji přejede auto. A ta jedna stará panna na to povídá: „Vidíš radši se nechala přejet.”

W dowcipach, ukazujących kobietę w różnych rolach społecznych, najwięcej przykładów dotyczy żony i teściowej (głównie w relacji z zięciem), nieznaczna natomiast ilość dowcipów ukazuje młodą kobietę i starą pannę. Wynika to z faktu, że wysoka pozycja kobiety w tradycyjnym patriarchalnym społeczeństwie zależała od tego, czy zawarła związek małżeński, czy nie. Dziewczęta były więc już od dzieciństwa przygotowywane do pełnienia w przyszłości roli żony i matki, z czasem stając się także teściowymi. Jak zauważa A. Christou:

Tradiční jazykový obraz dívky (resp. ženy obecně) je prostoupen hodnotami, které sdílela dřívejší společnost. Mladá dívka pro společenství představovala především „př́islib do budoucna” - měla se stát manželkou a matkou. Této budoucí roli bylo přizpůsobeno vše v její výchově. Teprve v manželství měla prokázat své kvality, ke kterým byla odmala připravována. Dá se říci, že celý dívčí věk směřoval k provdání a obřad svatby byl jakýmsi kulminačním bodem, definitivním přechodem do dospělosti a začátkem nové životní role (Christou 2020, s. 57)7.

Odzwierciedleniem takich postaw w naszym materiale jest $\mathrm{m} \nmid \mathrm{o}-$ d a k o b i e t a ukazana jako osoba, która daży do spełnienia oczekiwań społecznych wobec siebie i traktuje swojego partnera jako potencjalnego kandydata na męża. Odznacza się jednak naiwnościa, zakładając, że mężczyzna traktuje ją z równą powagą i że w przyszłości okaże sie odpowiedzialnym i zaufanym małżonkiem, a nie człowiekiem żyjącym na cudzy koszt.

W badanych dowcipach znajdują odbicie także współczesne problemy dziewcząt kilkunastoletnich. Przedstawiona jest bowiem na-

${ }^{7}$ Autorka konstatuje, że w związku z tym liczne egzemplifikacje tekstowe w języku czeskim, szczególnie zaś przysłowia, funkcjonują jako rady, nauki, wskazówki, jak powinna zachowywać się kobieta zamężna, na czym powinno opierać się dobre małżeństwo itd. Prowadzi to do tego, że „zejména tento konkrétní typ př́sloví o manželství je silně formován mužskou perspektivou. Žena je zde hodnocena z pohledu muže a více než jinde tu vystupuje do popředí tradiční patriarcháln uspořádání světa" (Christou 2020, s. 73) stoletnia matka, dla której posiadanie dziecka w tak młodym wieku nie jest niczym nadzwyczajnym. Wskazuje to na zmianę kulturowa jaka dokonała się w nowoczesnym społeczeństwie, w którym ciąża nastolatki nie jest już tabu, a inicjacja seksualna w coraz młodszym wieku nie stanowi wstydliwego problemu.

Znacznie więcej przykładów odwołuje się do roli ż o n y, która przedstawiona jest w negatywnym świetle jako osoba pełna wad, komplikujących wzajemne relacje w małżeństwie. Jedną z najwyraźniej zarysowanych w dowcipach przywar kobiecych, wyjątkowo dokuczliwych dla męża, jest kłótliwość, co odpowiada kulturowemu wizerunkowi żony swarliwej, skłonnej do kłótni i zrzędzenia, przywołującemu starożytny obraz Ksantypy - kłótliwej i złośliwej żony Sokratesa.

Wśród pozostałych cech będących w sprzeczności z modelem dobrej żony znajduje się jej skłonność do zdradzania męża. Niedochowanie wierności małżeńskiej zwykle odnosiło się do mężczyzny, wobec którego istniało społeczne przyzwolenie na zdradę, powodujące, że zdradzał częściej niż kobieta. Mąż ponosił też mniej dotkliwe konsekwencje braku wierności niż żona, dopuszczająca się zdrady ${ }^{8}$. Przeobrażenia współczesnych społeczeństw ewokują zmiany także obyczajowości i obecnie można zauważyć znaczny odsetek kobiet niedochowujących wierności w małżeństwie bądź w związku partnerskim, choć różnice zależą tu od wielu czynników, m.in. od miejsca zamieszkania. Jako egzemplifikacja powyższych tendencji mogą posłużyć badania przeprowadzone przez Instytut Badań Zmian Społecznych, zgodnie z którymi zdradza 61,4\% mężczyzn i 38,6\% kobiet, ale w dużych aglomeracjach miejskich jest to już 54,5\% mężczyzn

${ }^{8} \mathrm{Na}$ temat nierówności płci w tym zakresie pisze Ineza Drewniak: „W historii kobieta, która z pożądaniem patrzyła na mężczyzne, była uznawana za rozwiązłą i wulgarna, podczas gdy mężczyzna pożąający kobietę, miał do tego pełne prawo, bo wynikało to rzekomo z jego natury. W starożytnym Rzymie czy Grecji, kobieta najpierw należała do ojca, następnie do męża. Bardzo nieprzychylnie traktowane były prostytutki, ale mężczyźni, którzy korzystali z ich usług, nie podlegali krytyce, wszak przecież kobieta została stworzona po to, by zaspokajać potrzeby mężczyzny" (Drewniak 2019, s. 109). 
i 45,4\% kobiet $^{9}$. Potwierdzeniem tej prawidłowości może być także znaczna ilość dowcipów na temat zdrady małżonki poświadczona w naszym materiale.

Kolejna pejoratywna cechą żony ujętą w dowcipach jest jej rozrzutność. Cecha ta jest przeciwieństwem pozytywnie wartościowanej oszczędności i gospodarności, jaka charakteryzuje dobrą żonę, umiejącą odpowiednio i oszczędnie prowadzić dom, nie trwoniąc przy tym wspólnego majątku. Taki pożądany sposób podejścia małżonki do kwestii finansowych był podstawą bezkonfliktowych relacji w patriarchalnym modelu rodziny, w którym jeszcze na początku XX w. dominowało przekonanie, że za jej utrzymanie odpowiedzialny jest jedynie mąż. Jednak współcześnie w wyniku przemian społecznokulturowych role obu płci podlegają radykalnym zmianom. Tradycyjny podział ról, w którym mężczyzna jest żywicielem rodziny, staje się nieaktualny, niejednokrotnie bowiem to właśnie kobieta utrzymuje rodzinę lub co najmniej na równi z mężczyzną partycypuje w zaspokajaniu jej potrzeb. Współczesna żona zatem przestaje być zależna ekonomicznie od męża, który nie wywiera już wpływu na jej wydatki. W dowcipach jednak ujawnia się panujące nadal potoczne wyobrażenie o relacjach finansowych w małżeństwie oparte na kulturowym stereotypie płci.

Negatywnej ocenie podlega także brak umiejętności gotowania. Zajmowanie się kuchnią bowiem przynależy do pożądanych cech każdej kobiety, szczególnie zaś żony i matki. Zdolność przyrządzania posiłków dla całej rodziny jest jedną z czynności, jaką kobieta wykonywała od zarania dziejów i stanowi nieodłączny element obrazu kobiety - opiekunki ogniska domowego. Jak słusznie zauważa Anna Chrisou,

Ženy byly po staletí zodpovědné za vytváření domova jakožto klidného, bezpečného a útulného místa pro zbytek rodiny. Středem domu bývalo ohniště, krb, zdroj tepla, který žena opatrovala a na němž vařila. [...] Žena byla odedávna udržovatelkou

9 Por. https://mamadu.pl/145789,mezczyzni-zdradzaja-czesciej-najczesciej-zeznajoma-lub-kolezanka-z-pracy [dostęp 20.05.2021]. rodového a rodinného ohně a myšlenka rodinného krbu se táhne již od pradávna (Chrisou 2020, s. 80).

Antymodelowa małżonka w badanych dowcipach pokazana z przymrużeniem oka jest też wroga i niebezpieczna i dominuje w małżeństwie. Mamy tu do czynienia ze spotykanym od wieków odwróceniem ról: posłuszeństwo, uległość tradycyjnie przypisane do roli kobiety cechują mężczyznę (por. Ksantypę). Negatywna ocena postawy kobiety dominującej została upowszechniona także w czeskiej kulturze przez Aloisa Jiráska w zbiorze opowiadań z 1894 r. pt. Staré pověsti české w podaniu o Libuszy i Przemysławie i do dziś jest często przywoływana jako złota myśl, że Běda mužưm, kterým žena vládne. W naszym materiale ukazany jest obraz żony odrzucającej wyższość mężczyzny, obraz kobiety stanowczej, despotycznej, narzucającej mężowi swoją wolę. Wyśmiewany jest zatem mąż „,pantoflarz”, który pozwala żonie na zdobycie nad nim przewagi, co w konsekwencji wyzwala u niego poczucie zagrożenia.

Z powyższymi pejoratywnymi cechami małżonki powiązana jest kolejna jej własność - mściwość. Kobieta bowiem, która ma poczucie własnej wartości, odrzucająca męską dominację, jest dla męża niebezpieczna także z tego powodu, że ma odwagę i może zdecydować się na odwet za krzywdy doznane od mężczyzny, np. za zdradę czy zawiedzenie zaufania. Zranienie staje się dla niej motywem do zemsty w różnorodnej formie, szczególnie zaś dążenia do narażenia małżonka na dotkliwe straty finansowe, co oddane zostało w analizowanych dowcipach.

Innym przykładem niepożądanej cechy małżonki jest manipulacja. Badane dowcipy utrwalają stereotyp kobiety-manipulatorki, która dążąc do osiągnięcia swoich celów, nie liczy się z mężem, wykorzystuje różne okoliczności oraz swoje walory (np. wdzięk, uroda) i przeinacza oraz nagina fakty.

Przedstawione w dowcipach w krzywym zwierciadle relacje małżeńskie kształtują obraz żony z perspektywy męża. Jest ona zatem postrzegana negatywnie, a jej wszelkie opisane powyżej przywary powodują, że przynosi mężowi jedynie nieszczęście i wywołuje jego cierpienie nie tylko moralne, ale także fizyczne. 
Kolejną rolą społeczną, w jakiej występuje w naszym materiale kobieta, jest rola teściowej - matki żony, ponieważ szczególnie wyraźnie zarysowane w dowcipach są jej relacje z zięciem, co świadczy o androcentryzmie tego typu tekstów ${ }^{10}$. Stereotypowa te ś c i o w a jest zatem przede wszystkim osobą złośliwą, która nie stroni od uszczypliwości, czym sprawia przykrość zięciowi. Celowo mu dokucza, kieruje do niego zgryźliwe uwagi, przez co jej obecność staje się męcząca dla zięcia i wywołuje jego rozdrażnienie.

Dowcipy uwypuklają także inną cechę charakterystyczną dla matki żony, która z perspektywy mężczyzny jest oceniana negatywnie. Chodzi o przekonanie teściowej, że wie wszystko i wie to lepiej od zięcia, z czego wynika narzucanie mu swojego zdania. Owa apodyktyczność ma także zasadniczy wpływ na pejoratywny kształt relacji zięć - teściowa.

Powyższe cechy przypisywane teściowej stanowią przyczynę tego, że budzi ona postrach u zięcia, który próbuje przeciwstawić się nieodpowiedniemu traktowaniu przez matkę żony, dokonując mniej lub bardziej jawnych ataków na nią. Konflikt zięć - teściowa przejawia się wyraźnie w licznych dowcipach reprezentujących tzw. czarny humor:

„Mohl byste mi říct, kolik u vás stojí jeden diskrétní pohřeb?”

"No záleží na tom, jakou rakev si vyberete."

„Potřeboval bych nějakou pevnou a hlavně zvukotěsnou, to víte, tchýně není ještě tak úplně po smrti."

Omawianą tu kategorię ról społecznych, jakie zostały zaprezentowane w analizowanych dowcipach, zamyka st ar a panna. Nega-

${ }^{10}$ Należy tu podkreślić, że stereotypowy obraz teściowej zwykle odnosi się do matki męża, obejmuje zatem relacje synowa - teściowa. Jest to wynikiem powszechnie przyjętych społeczno-kulturowych wzorców tradycyjnej rodziny, w której „Problematický býval vždy zejména vztah tchyně a snachy [...]. Dříve se totiž novomanželky po svatbě zpravidla stěhovaly $\mathrm{k}$ rodině svého muže, kde však byla hospodyní a paní domu manželova matka. V nové rodině byly cizí a nejednou s nimi bylo zle nakládáno [...]. Neobvyklé prý nebylo ani »výchovné« bití mladé snachy ze strany manželových rodičű" (Chrisou 2020, s. 95-96). tywny stereotyp kobiety niezamężnej wypływa $\mathrm{z}$ wielowiekowego podziału ról społecznych, zgodnie z którym kobiecie przypisana została rola żony i matki. Jak twierdzi Anna Christou,

V dobách, kdy dívky byly vychovávany především pro manželství a ženy byly ekonomicky zcela závislé na mužích, byly zmařené naděje na sňatek opravdovou ránou. Stará panna byla pro smích a pro ostudu, ve společnosti neměla dobré postavení (Chrisou 2020, s. 48-49).

Starzejąca się niezamężna kobieta zatem stanowiła obiekt kpin, żartów i pogardy. Utrwalił się jej obraz jako kobiety zgryźliwej, surowej i nieprzystępnej. W badanym materiale szczególnie wyeksponowany został negatywny stosunek starej panny do seksualności.

\section{Wygląd zewnętrzny}

Kobieca fizyczność to kategoria, która w badanych dowcipach jest poświadczona mniej licznie, niż omawiane powyżej dwie klasy. Zarejestrowaliśmy następujące cechy kobiecego wyglądu:

- z w i e ki e m t r a c i u r o d ę: Muž povídá své ženě: „Víš miláčku ty jsi jiná než ostatní dívky..."

Žena odpoví: „Jaké jsou ostatní dívky?”

Muž: „Hezčí.”

- j e s t ot yła: Žena:

„Dneska ráno v metru tři chlapi vstali, aby mi uvolnili místo.” Muž:

"A vešla ses?"

- ma mały bi u st: Víte, jaký je rozdíl mezi encyklopedií a podprsenkou? Žádný, v obou často hledáme marně!

$-\mathrm{ub}$ i e r a s i ę $\mathrm{w}$ y z y w a j a c o: Jeden policista povídá jedné slečně, která měla velmi odvážný výstřih bez podprsenky:

„Slečno, už jste mi ukázala své poklady, tak ted' mi ukažte ještě vaše doklady.”

- dłu go s z y kuje s i ę do w y j ś c i a: Povídají si dva kamarádi:

"Proč chodíte se svou manželkou jenom do nočních lokálů?”

„Než se oblékne, všechno už je zavřené!" 
Obraz kobiety, jaki wyłania się z naszego materiału, stanowi zaprzeczenie silnie utrwalonego kulturowo stereotypu kobiety jako istoty pięknej, zgrabnej, atrakcyjnej i pełnej wdzięku. Oczekiwania społeczno-kulturowe odnośnie do kobiecego ciała, w znacznym stopniu narzucone przez męski punkt widzenia, wykreowały idealny model piękna kobiecego, do którego dążyły kobiety, aby zyskać aprobatę i uznanie społeczne. Wszelkie natomiast odstepstwa od ideału traktowane były jako niepożądane, wręcz naganne. Według Mieczysława Balowskiego określenie kobiety mianem ptci pięknej jest silnie uwarunkowane kulturowo, ponieważ uroda kobieca ,jest jednym z ważniejszych elementów, które mężczyzna postrzega u kobiety. Bazuje to na słabości człowieka wobec piękna w ogóle [...]. Czasami jest ono ważniejsze niż zalety umysłu” (Balowski 2018, s. 85).

W konsekwencji ów narzucony wizerunek kobiecego ciała przyczynił się do tego, że ,wielokrotnie funkcja kobiety była okrojona do tzw. bransoletki, która ładnie wygląda na nadgarstku, dodaje uroku i klasy całej stylizacji, ale nie spełnia jakiejś szczególnej roli, dla osoby, która ją zakłada" (Drewniak 2019, s. 93).

Na podstawie przytoczonych powyżej dowcipów należy stwierdzić, że negatywnie oceniana jest przedstawicielka płci pięknej, która z wiekiem traci swój podstawowy atrybut, jakim jest piękno zewnętrzne. W miarę bowiem upływu lat procesy biologiczne starzenia się kobiecego organizmu przyspieszają i kobieta tra c i u rod ę, często także smukła sylwetkę, przybiera na wadze, co powoduje, że j e s t o tyła. Wówczas jej wygląd staje się przywarą i poddawany jest krytyce przez otoczenie, które zarzuca kobiecie, że nie dba o siebie.

$\mathrm{Z}$ drugiej jednak strony nasz materiał wskazuje, że kobieta podporządkowuje się dążeniu do narzuconego ideału, dba o ciało, stosując nieustannie dietę w celu osiągnięcia odpowiedniej figury, co staje się jej „sposobem na życie”. Przytoczmy jeszcze przykład, który dobrze obrazuje tę sytuację:

„Děvče, copak budeš dělat, až budeš tak velká, jako tvoje matka?” "Držet dietu."
Męski punkt widzenia w kształtowaniu stereotypowego wizerunku wygladu zewnettrznego kobiety najwyraźniej przejawia się w tych dowcipach, w których mowa jest o kobiecych piersiach. Zgodnie bowiem z potocznym wyobrażeniem uznaje się jako istotne posiadanie przez kobietę dużego biustu. Jeśli jednak ma ona ma ł y b i u s t, staje się obiektem kpin i żartów.

W naszym materiale zarejestrowaliśmy także teksty, które odnoszą się do kobiecego stroju. Negatywnie oceniana jest kobieta u bi e $\mathrm{raj}$ ą c a s i ę w y z y w a ją c o, która ubiorem zwraca na siebie uwagę, prowokuje odsłoniętym i nadmiernie wyeksponowanym ciałem. Z męskiej perspektywy ujemnie wartościowana jest także kobieta, która długo s z y kuje się do wyjścia, szczególnie na wieczorne przyjęcie.

\section{Zawód}

Wśród dowcipów dotyczących kobiet stosunkowo niewiele odwołuje się do wykonywanych przez nie profesji. W naszym materiale zostały poświadczone takie zawody ${ }^{11}$, jak:

- s e k r e t a r k a: „Moje sekretářka je jako vlaštovka,” chlubí se vedoucí odbytového úseku.

„Tak pilná?”

„Kdepak. Pořád sedí na telefonním drátě.”

Matka se ptá dcery, která začala pracovat jako sekretářka: „A neobtěžuje tě šéf?”

Dcera se usměje: „Ani ne, mami! Já mám sex ráda...”

- n a u c z y c i e 1 k a: Sedí tři ženský v parku na lavičce, jedna je hnusná, druhá tlustá a ta třetí je taky učitelka!!!

- s p r z e d a w c z y n i: Dvě prodavačky si povídají za regálama. Přiběhne třetí a povídá:

„Holky, v obchodě jsou zákazníci!”

„Tak bud'me potichu, oni zase odejdou!"

${ }^{11}$ Nie bierzemy tu pod uwagę tych zawodów, których pojawienie się w badanym materiale motywowane jest tematem dowcipu. 
- p r a c o w n i c a p o c zt y: „Pane Hromádka,” zajímá se poštačka, „proč vás vyhodili z práce?"

„Kvůli kašli.’

„Jak to?” diví se drbna. „Za to, že jste nemocný, přece nemůžete.”

„No jo, ale já jsem kašlal na práci!”

- d e n t y s t k a: Dentistka drží pacientovi u pusy vrtačku a ř́ká:

„Pamatuješ si, jak si mě ve škole tahal za vlasy.”

- p r o s t y t u t k a: Muž se snaží navázat kontakt s mladou dívkou: „Máme pěkný počasí."

Ona nic.

„I včera bylo pěkně.”

Opět nic.

„A co myslíte, jak bude zítra?”

„Poslouchej, já jsem šlapka a ne meteorologická stanice.”

Nieznaczna ilość kobiecych profesji poświadczonych w badanych dowcipach potwierdza tendencję, że na kształtowanie stereotypowego wizerunku płci pięknej mają wpływ przede wszystkim cechy charakteru i osobowości oraz role społeczne i postawy. Zarejestrowane bowiem w naszym materiale zawody stanowią egzemplifikację konkretnej przywary kobiecej, która w wyniku uogólnienia, staje się cechą charakteryzującą wszystkie kobiety wykonujące określony zawód a tym samym funkcjonuje jako stereotypowa negatywna ocena danej profesji ${ }^{12}$. W związku z powyższym możemy stwierdzić, że sekretarka jest gadatliwa i rozwiazła seksualnie, nauczycielka - odpychajaca i otyła, sprzedawczyni jest leniwa, pracownica poczty natomiast to plotkarka, a dentystka, ujawniając sadystyczne skłonności, dąży do zemsty, prostytutka natomiast jest pragmatyczna i interesuje ją jedynie zysk.

${ }^{12}$ Warto tu dodać, że w dowcipach daje się zauważyć pewna asymetria w przedstawianiu zawodów kobiecych i męskich, polegająca na odwoływaniu się do profesji kobiecych mniej prestiżowych, a męskich cieszących się większym uznaniem społecznym. Na podobna tendencje we frazeologii zwróciła uwage Katerina Kedron, badająca wizerunek kobiety i mężczyzny we frazeologii słowiańskiej (por. Kedron 2014, s. 110).
Zaprezentowany powyżej utrwalony w czeskich dowcipach wizerunek kobiety stanowi fragment całościowego językowo-kulturowego obrazu kobiecości, jaki ukształtował się w czeszczyźnie i jaki jest odtwarzany m.in. w oparciu o badania leksykalno-semantyczne (por. np. Christou) ${ }^{13}$, szczególnie zaś frazeologiczne (por. np. Balowski 2018, Kedron 2014). Poszczególne obrazy wzajemnie się przenikają i uzupełniają, zachowując także swoją specyfikę. Jedną z cech typowych dla naszego materiału jest częste odwołanie do seksualności z wykorzystaniem słownictwa wulgarnego, co potwierdza przynależność badanych dowcipów do tekstów reprezentujących bulwarowy humor, w których stosowanie wulgaryzmów jest podstawowym zabiegiem osiagania komizmu, zaliczanym do prostych mechanizmów ogólnokomicznych (por. Buttler 2001) ${ }^{14}$.

Omawiany tu obraz kobiety jest obrazem jednostronnym, utrwalającym jej negatywny stereotyp, stojący w opozycji do wyidealizowanego modelu kobiecości zgodnego z oczekiwaniami społecznymi ukształtowanymi na przestrzeni wieków w kulturze Zachodu (por. Balowski 2018, s. 72n.). Dowcipy demaskują nierealność takiego podejścia i wskazują na trudności w dążeniu kobiety do osiągnięcia ideału i niemożność zrealizowania go w rzeczywistości, co ujmuje m.in. następujący przykład:

${ }^{13}$ Autorka uwzględniła tu obszerną egzemplifikację tekstową: „Obraz ženy $\mathrm{v}$ této studii rekonstruujeme především prostřednictvím dokladů $\mathrm{z}$ české slovn zásoby včetně frazeologie, textů lidových písní, drobných folklorních žánrů a částečně i na základě klasické české literatury. [...] Primárními zdroji se proto v této práci staly jednak české výkladové, frazeologické, synonymické a etymologické slovníky (jež poskytují tzv. data jazyková, resp. systémová), jednak sbírky českých př́sloví a rčení, sbírky českých a moravských lidových písní, a jednak též klasická česká literatura (zejm. kanonická díla 19. a 20. století)" (Christou 2020, s. 25). A. Christou przedstawia obraz kobiety w następującym porządku: młoda dziewczyna, żona, matka, stara kobieta, ciało kobiety.

${ }^{14}$ Mamy tu na myśli tzw. dowcipy agresywne, wykorzystujące wulgaryzmy, słownictwo obraźliwe i brutalizację obrazowania. Na temat podziału dowcipów na agresywne i niewinne por. Brzozowska 2008. 
Být ženou je těžké:

Musíte myslet jako muž,

chovat se jako dáma,

vypadat jako děvčátko

a dř́t jako kůn.

Z drugiej jednak strony mamy ideał kobiety widziany z perspektywy mężczyzny - anty-ideał w ujęciu humorystycznym:

Jaká je dokonalá žena?

Slepá, hluchá a hloupá nymfomanka, která vlastní obchod s lihovinami.

Konkludując, należy podkreślić, że zaprezentowane w artykule przykłady dowcipów odnoszących się do kobiety niejednokrotnie reprezentują męski punkt widzenia, co ma swoje źródło w androcentryzmie patriarchalnej kultury Zachodu. Jak bowiem słusznie zauważa Artur Rejter,

Gdy spojrzeć na przykład na historię zachodniej myśli filozoficznej dotyczącej kobiety i mężczyzny, łatwo zauważy się bezdyskusyjna dominację męskości jako cechy człowieczeństwa w ogóle. Istota ludzka, według myślicieli, to właściwie tylko mężczyzna, a jeśli już pojawi się w refleksji wątek poświęcony kobietom, zyskuje on wymiar nacechowanego, występującego w roli znaczącego, najczęściej o przypisywanych mu negatywnych właściwościach, szczegółu na patriarchalnym, dominującym tle (Rejter 2013, s. 56).

Przedstawiony zatem w czeskich dowcipach wizerunek kobiety ma charakter uniwersalny, międzynarodowy.

\section{Literatura}

A t t a r d o S., 1994, Linguistic Theories of Humor, Berlin-New York.

B a 1 o w s k a G., 2014, Wizerunek mężczyzny w czeskich dowcipach, [w:] Mężczyzna w literaturze $i$ kulturze, red. Grażyna Różańska, Pruszcz Gadński-Słupsk 2014, s. 335-348.

B a 1 o w s k i M., 2018, Obraz świata w czeskiej frazeologii, Poznań

B a r t m ińs k i J., 2006, O pojęciu językowego obrazu świata, [w:] idem, Językowe podstawy obrazu świata, Lublin, s. 11-21.

B a r t m iń s k i J., 2007, Stereotypy mieszkaja w języku. Studia etnolingwistyczne, Lublin.

B e rg s o n H., 2000, Śmiech. Esej o komizmie, Warszawa.
B o r e c ký V., 2000, Teorie komiky, Praha.

B r zo z ow s k a D., 2008, Polski dowcip etniczny, Opole.

B u t 1 e r D., 2001, Polski dowcip językowy, Warszawa.

$\mathrm{C}$ h r i s o u A., 2020, Žena v českém tradičním obrazu světa. Etnolingvistická studie, Praha.

D e a u x K., Lew is L., 1984, The structure of gender stereotypes: Interrelationships among components and gender label, ,Journal of Personality and Social Psychology" 46, s. 991-1004.

D r e w n i a k I., 2019, Jak być kobieta? Kreowanie stereotypów i modele kobiecych zachowań prezentowane w reality shows, „Studia krytyczne” 8, s. 91-114.

Humor i karnawalizacja we współczesnej komunikacji językowej, 2007, red. J. Mazur, M. Rumińska, Lublin.

Humor w perspektywie kulturowo-językowej, 2013, red. M. Karwatowska, L. Tymiakin, Lublin.

K a dłu bi e c D.K., 1995, Górniczy śmiech. Komizm ludowy pogranicza czeskopolskiego, Wrocław.

$\mathrm{K}$ ą ś J., Kulturowy stereotyp mężczyzny i kobiety $w$ środowisku wiejskim (na materiale gwar orawskich), [w:] Pteć w języku i kulturze, ,Języka a kultura”, t. 9, s. 119-130.

K e d r o n K., 2014, Genderové aspekty ve slovanské frazeologii (na materiálu běloruštiny, polštiny a češtiny), Praha.

K r z y ż a n o w s k i J., 1977, Paralele. Studia porównawcze z pogranicza literatury i folkloru, Warszawa.

M a d a l E., 2003, Kobiecość i męskość. Popularne opinie i badania naukowe, Warszawa.

Rejter A., 2013, Pleć-jezyk-kultura, Katowice.

R i c h te r ová S., 1997, Ticho a smích, Praha.

S i monides D., 1984, Bery to nie tylko gruszki czyli rzecz o humorze ślaskim, Opole.

S k udrzyk ow a A., 2000, Czym bawi kawat śląski?, [w:] Świat humoru, Opole, s. $149-155$.

Świat humoru, 2000, red. S. Gajda, D. Brzozowska, Opole. 